УДК 17:378

\title{
ПРИНЦИПИ ЕТИКИ ПЕДАГОГА ВИЩОЇ ШКОЛИ: КЛАСИКА І СУЧАСНІСТЬ
}

\author{
Сухорукова Т. Г., к. е. н., доцент \\ Шраменко О. В., к. е. н., доцент (УкрДУЗТ)
}

\begin{abstract}
Статтю присвячено питанням розвитку педагогічної етики з урахуванням класичних принщипів ї̈ побудови. Класичні принщипи педагогічної етики сформульовані більи як століття тому, але і сьогодні вони актуальні. Найбільш важливими принципами педагогічної етики є: неупередженість; конфіденційність; точне виконання професійних обов'язків; уникнення конфліктів. Сучасна педагогіка повинна надати національній економіці такого працівника, який є творчою особистістю, мислячим стратегічно, $\epsilon$ істинно інтелігентною людиною. Діяльність педагога повинна містити мінімум конфліктних ситуацій і максимум можливостей вирішення конфліктів.
\end{abstract}

Ключові слова: педагогічна праця, етика, педагогічна етика, моральна культура, криза педагогічної культури, кодекс професійної етики, принципи педагогічної етики.

\section{ПРИНЦИПЫ ЭТИКИ ПЕДАГОГА ВЫСШЕЙ ШКОЛЫ: КЛАССИКА И СОВРЕМЕННОСТЬ}

\author{
Сухорукова Т. Г., к. э. н., доцент \\ Шраменко Е. В., к. э. н., доцент (УкрГУЖТ)
}

Статья посвящена вопросам развития педагогической этики с учетом классических принщипов ее построения. Классические принципы педагогической этики сформулированы более века тому назад, но и сегодня они актуальны. Наиболее важными принципами педагогической этики являются: беспристрастность; конфиденциальность; точное исполнение профессиональных обязанностей; избегание конфликтов. Современная педагогика долюна предоставить национальной экономике такого работника, который является творческой личностью, мыслящим стратегически, есть истинно интеллигентным человеком. Деятельность педагога должна содержать минимум конфликтных ситуаций и максимум возможностей разрешения конфликтов.

Ключевые слова: педагогический труд, этика, педагогическая этика, нравственная культура, кризис педагогической культуры, кодекс профессиональной этики, принципы педагогической этики.

\section{PRINCIPLES OF HIGH SCHOOL TEACHER ETHICS: CLASSICS AND MODERNITY}

Sukhorukova T. G., candidate of Economic Sciences, associate Professor Shramenko E. V., candidate of Economic Sciences, associate Professor (UkrSURT)

The article deals with the development of pedagogical ethics, taking into account the classical principles of its construction. Pedagogical ethics is defined as the science of moral

(C) Сухорукова Т.Г, Шраменко O.B.

Вісник економіки транспорту і промисловості № 69, 2020 
requirements development laws, which are outlined by the pedagogical work features. These moral requirements of pedagogical work are manifested both vertically and horizontally in the teacher activity. The article examines objective features of the external environment that determine the formation of pedagogical ethics. The main feature of constructing pedagogical ethics is to reduce the time of interaction (cooperation) of a teacher with a student: the teacher in a short period of time must establish contact with the student, set out the training material, determine the quality of assimilation of this material by the student and evaluate the student's residual knowledge. It is noted that despite the fact that the classical principles of pedagogical ethics were formulated more than a century ago, today they are relevant and endowed with the property of self-development. The main pedagogical ethics principles are: impartiality, objectivity; confidentiality; accurate performance of professional duties; avoidance of potential or explicit conflicts. It is emphasized that modern pedagogy should provide the national economy with such an employee, who is a creative, truly intelligent person with a strategic way of thinking. Emphasis is placed on the fact that modern pedagogical ethics needs methods for an objective assessment of a teacher's own activity; non-standard systems of student censure through the reward mechanism, formation of a modern code of professional ethics for teachers; system of spiritual and moral self-development and self-realization; new techniques to encourage student research. In conclusion, it is noted that the teacher activity should contain a minimum of conflict situations and a maximum of conflict resolution. Important factors are teacher's general culture and patriotic identity.

Key words: pedagogical work, ethics, pedagogical ethics, moral culture, pedagogical culture crisis, code of ethics, principles of pedagogical ethics.

Хто рухається вперед у науках, але відстає в моральності, той більше йде назад, ніж вперед.

(Аристотель)

Постановка проблеми. Вимоги, що пред'являються сучасною економікою до молодих спеціалістів, визначають напрями розвитку педагогічної праці. Сучасний педагог вищої школи повинен не тільки вдосконалювати свої професійні знання, а й розвивати культуру педагогічної діяльності. I сьогодні $\epsilon$ актуальними слова давньогрецького філософа Сократа: «Виховання - справа важка, і поліпшення його умов - один із священних обов'язків кожної людини, бо немає нічого важливішого, як освіта самого себе і своїх ближніх» [1].

Порівнюючи праці педагогівкласиків та науковців сучасності [2-11], слід відзначити, що за останні майже три десятиліття розвитку вітчизняної педагогіки умови навчання кардинально змінилися:

1) сьогодні більшість студентів денної форми навчання (особливо старших курсів) поєднують навчання з роботою;
2) контрактна форма навчання стала переважаючою, що опосередковано впливає на побудову взаємин «педагог - студент»;

3) йде постійне скорочення годин аудиторних занять і одночасне збільшення годин самостійної роботи;

4) підвищується значення прикладних знань;

5) суспільство все більше орієнтується на матеріальні цінності, в той же час рейтинг духовно-моральних цінностей знижується;

6) в суспільній свідомості відзначається розмитість моральних цінностей та ідеалів у суспільства, в тому числі і у частини інтелігенції, знижується віра в краще майбутне розвитку сучасної цивілізації.

Природно, що ці зміни впливають на етику педагогічної діяльності.

Етика педагогічної праці $є$ досить вивченим напрямком наукової думки. У 
спеціалізованих вищих навчальних закладах вона включена до переліку обов'язкових навчальних дисциплін. Але оскільки сама етика - динамічна соціальна наука, яка схильна до впливу чинників, про які ми говорили вище, питання іiі розвитку як i раніше залишається актуальним.

Аналіз останніх досліджень. Педагогічна праця сучасними дослідниками розглядається в більшості випадків як особлива сфера суспільної діяльності, в якій має місце взаємодія людини, що володіє моральною культурою, i зростаючою людиною, яка опановує основи цієї культури. Особливість педагогічної праці полягає в тому, що предметом цієї праці $\epsilon$ дитина (вихованець, студент) - людина, що володіє певним рівнем свідомості. У той же час дитина, як предмет педагогічної праці, $\epsilon$ об'єктом впливу багатьох інших чинників, що формують особистість [2].

Загальновизнаною аксіомою $\epsilon$ класичне визначення етики - системи універсальних і специфічних моральних вимог і норм поведінки, що реалізуються в процесі суспільного життя [3].

Багато вчених $[2,4,8,11,12]$ єдині в тому, що педагогічна етика - це наука про педагогічну моральність, основними елементами якої $\epsilon$ чесність, доброзичливість, гуманність, повага до особистості, почуття відповідальності за результати праці, дотримання дисципліни й т. ін. Педагогічна етика - це наука про закономірності розвитку моральних вимог, що породжуються особливостями педагогічної праці, які проявляються у взаєминах між вчителем і учнем, вчителями та батьками учнів, між вчителями та адміністрацією, а також у складних взаєминах в самому педагогічному колективі, визначальною умовою яких $\epsilon$ особистісні і професійні якості вчителя (педагога) [4].

Дослідники в області педагогічної етики рідко пропонують змінити їі сутність і зміст. Але більшість 3 них відзначають всі ознаки кризи педагогічної культури: зниження якості освіти; відсутність яскравих ознак творчості в освітній діяльності; відсутність загального авторитету педагогічної праці; низький рівень зацікавленості студентів брати участь в наукових розробках і т. д. [5, 6].

Нинішня педагогічна теорія i практика рясніють прикладами, коли традиції зменшуються i поступово втрачаються, а інновації виникають без філософського i психологічного обгрунтування, аналізу організаційнопедагогічних аспектів розвитку [5].

Виробничники підходять до етичних питань педагогічної праці з іншого боку [9, $10,13]$. Безумовно, для них важливо, щоб молодий спеціаліст розбирався в своїй професії i міг швидко пройти період трудової адаптації на виробництві. Але сучасному керівникові підприємства важливо, щоб працівник був творчою особистістю, що мислить стратегічно, був істинно інтелігентною людиною. Саме цією вимогою пояснюється наявність кодексів професійної етики адвокатів, нотаріусів, суддів, лікарів, журналістів і т. д.

Популярним напрямом наукових досліджень в галузі професійної етики є вивчення взаємозв'язку релігійних форм і моральних норм суспільства. Майже 100 років тому видатний вчений Макс Вебер переконливо довів: західний капіталізм сформувався не на «первинному накопиченні», а на потужному моральному фундаменті - протестантській етиці, яка 3 точки зору економічних інтересів характеризується бережливим способом життя, економією на витратах, чесності, скромності, працьовитості [7].

Важливим фактором етики $\epsilon$ самовиховання. «Виховуй в собі Людину ось що найголовніше. Інженером можна стати за 5 років, вчитися ж на людину треба все життя. Виховуй в собі людську душу. Найголовніший засіб самовиховання душі краса. Краса в широкому сенсі - і мистецтво, i музика, i сердечні стосунки 3 людьми» [14].

Велику кількість робіт в області педагогічної етики присвячено проблемі 
педагогічного такту, який визначає успішність навчально-виховної роботи [3, $13,15]$. Уміння педагога тримати себе 3 гідністю i витримкою в педагогічному колективі, зі студентами (при необхідності і з батьками студентів), а також здатність знати міру свого впливу на студентів, вміння знайти підхід до них і побудувати оптимальні виховні відносини 3 урахуванням загальновизнаних принципів виховання - це є педагогічний такт.

Роль педагогічної етики неоціненна в процесі підготовки фахівця. Вона бере на себе розвиток етичної поведінки студента колишнього школяра, і поступово підводить його до ділової професійної етики. У сучасному бізнесі не можна ігнорувати правила професійної етики, інакше можна втратити бізнес. Сучасним підприємцям необхідні знання професійної етики як інструменту управління діловою репутацією, яка $є$ в кінцевому рахунку фактором максимізації прибутку підприємства [16].

Метою даної cmammi $є$ аналіз i оцінка класичних принципів педагогічної етики, а також їх розвиток у вітчизняних вишах 3 урахуванням реалій сучасної економіки.

Викладення основного матеріалу. Педагогічна етика - це сукупність моральних норм, що визначають ставлення людини до свого професійного обов'язку, а, отже, i до людей, з якими людина пов'язана в силу характеру своєї професії, і до суспільства в цілому [17].

Правомірним буде тут вказати на слова видатного російського письменника i публіциста Н. Г. Чернишевського, який в своїх статтях писав, що освіта включає в себе три якості: великі знання, звичку мислити і благородство почуттів [18].

Спеціальні дослідження показують, що студенти більше цінують у викладачеві тактовність, доброту, справедливість, розуміння вікових проблем, бажання надати студенту допомогу в оволодінні програмним матеріалом, товариськість, сумлінність, працьовитість, стриманість, віру в пізнавальні здібності того, хто навчається, терпіння, вимогливість і ряд інших професійно значущих особистісних рис. Але головне, чим дорожить вихованець, - це душевна щедрість, щирість і сердечність відносин [8].

Педагогічна етика базується на класичних принципах професійної етики: неупередженість, об'єктивність; конфіденційність; посадова старанність; точне виконання професійних обов'язків; уникнення потенційних або явних конфліктів [9]. Ці ж принципи покладені і в професійну етику педагога.

Неупередженість та об'єктивність педагогічної етики виражається, перш за все, в доброзичливості і прихильності до всіх студентів. Ставлення «викладач студент» - це відносини психологічного паритету, за формулою «дорослий дорослий», але не відносини психологічної опіки за формулою «батько - дитина». Викладач не має право завищувати оцінку, опиняючись в ролі «батька, який розуміє i підтримує», з одного боку, але не має права i занижувати оцінку, ставлячи себе в позицію «батька, що повчає» $[11,19]$.

3 іншого боку, реалізація цього принципу педагогічної етики передбачає відсутність зарозумілості, вміння визнати свої помилки і дати об'єктивну оцінку власній діяльності та її результатам.

Розглядаючи

принцип неупередженості та об'єктивності, необхідно приділити особливу увагу питанню протидії проявам корупції у вищій школі. Корупцію 3 етичної точки зору, доцільно сприймати як приниження власної гідності, як шкоди репутації вишу.

Принцип конфіденційності передбачає особливі відносини в системі «педагог - студент» і «педагог - педагог». Студент повинен розуміти, що відносини 3 педагогом у вищій школі демократичніші, ніж в загальноосвітній школі.

3 іншого боку, особливої конфіденційності вимагає критика дій студента. Як тут не згадати слова Конфуція: «До молодих людей не можна ставитися 
зверхньо. Дуже може бути, що, подорослішавши, вони стануть видатними мужами» [1]. Засуджувати студента необхідно наодинці. Але навіть самі незначні успіхи студентів повинні бути відзначені викладачем у присутності всього колективу. Викладач повинен вибирати такі методи роботи, які заохочують в студентах розвиток позитивних рис i взаємин: самостійності, самоконтролю, самовиховання, бажання співпрацювати i допомагати іншим.

Принцип конфіденційності важливо дотримуватися i в стосунках «педагог педагог». Цей принцип виражається в дотриманні чесності в питаннях авторських прав, в протистоянні плагіату і порушення правил цитування. Конфіденційність важливо зберігати в колегіальних науководослідних процесах, особливо до узгодженого публічного представлення результатів досліджень [20].

Не менш важливим принципом педагогічної етики є посадова старанність, яка має бути підпорядкована одній 3 мудростей давньогрецького філософа i математика Піфагора: «будь другом істини до мучеництва, але не будь їі захисником до нетерпимості» [1].

Педагог зобов'язаний нести відповідальність перед студентами і колегами за наповнюваність, точність, об'єктивність того наукового знання, яке він пропонує науковій і навчальній аудиторії. При цьому необхідно враховувати дуалізм роботи педагога, який виступає в двох іпостасях: викладач і науковець. Необхідно підкреслити, що педагог вищої школи - це, перш за все, вчений. При описі його обов'язків введено поняття «друга половина дня», по якій він звітує науковими працями, публікаціями, захистом дисертацій і т. д. [21].

У моральних кодексах науковця деякі вчені [12] відзначають таку важливу його складову, як моральна відповідальність за виховання молодого покоління вчених i студентів в дусі гуманізму, наукової цінності i порядності. Показниками високого культурного рівня сучасного педагога стають такі якості, як вдумливість, критичність i самокритичність, постійна творча напруга [22].

Безумовно, ринкова економіка чинить активний вплив i на навчальний процес. Сьогодні педагог не може користуватися тільки традиційними методами навчання. Але за новими методами навчання (більш технічно оснащеними) не повинна зникнути духовна складова освітнього процесу.

Етика педагогічної роботи вимагає від педагога постійної самоосвіти. На думку B.I Андрєєва [6] два принципи - принципи безперервного духовно-морального саморозвитку і самореалізації педагога - $\epsilon$ найголовнішими i визначальними у професійній діяльності педагога.

Практика показує, що комп'ютеризація планомірне призводить до зниження рівня загальної і спеціальної граматики не тільки серед студентів, але $\mathrm{i}$ серед педагогів. В якості рекомендації, хотілося 6 наголосити на необхідності проведення серед педагогів аудіо диктантів.

Однак, об'єктивна реальність така, що у більшості педагогів сьогодні не вистачає ні часу, ні сил, ні фінансових коштів на самоосвіту, в тому числі і на духовно-моральний саморозвиток, на залучення до цінностей культури через відвідування театрів, виставок, читання педагогічної і мистецької літератури і т. д.

Але якщо розглядати «посадову старанність» педагога, то не можна не відзначити i другу сторону процесу навчання. В рамках даної статті, відзначимо лише етичне ставлення студента до педагога в момент здачі завершальній перевірки (іспиту чи заліку). Крайнім виявом відсутності елементарної етики $\epsilon$ багаторазова здача іспиту. Викладач стає заручником ситуації i змушений зустрічатися зі студентом стільки раз, скільки цього захоче студент. Відправляючи студента із завданням вивчити матеріал глибше і грунтовніше, викладач скорочує час, який він міг би присвятити науковій 
роботі. Кількість перездач має бути чітко зафіксована i контролюватися 3 боку деканатів.

Точне виконання професійних обов'язків педагогом $\epsilon$ безумовним орієнтиром професійної діяльності студента в майбутньому. Заохочення наукової діяльності студента активізує його творчий потенціал. Приклад педагога-вченого змушує деяких студентів обирати наукову стезю. Як сказав Сенека: «Довгий і мало корисний шлях настанов, короткий i дійсний шлях прикладу» [1].

Точне виконання професійних обов'язків передбачає не тільки виконання своєї роботи у відповідності 3 посадовою інструкцією, але й безперервна самоосвіта, самовиховання педагога Самовдосконалення має стати обов'язковою його метою.

Наука - це не «статичні» знання, які постійні та непорушні. Сьогодні наука - це діяльність 3 виробництва нових знань та оновлення існуючих. Наукові знання, як відображена дійсність, представлені людині на особливій мові, які отримали системну організацію, сформувалися в струнку теорію, набувають здатність саморозвитку. Вся цінність науки в тому, якою мірою і 3 якою достовірністю вона може прогнозувати майбутні події [15].

Педагог вищої школи повинен не тільки зберігати знання, які він передає студентам, але й примножувати знання, щоб студенти бачили: ї наставник також розвивається, вносить нові, сучасні знання в свою педагогічну практику. Досвід показує, що студенти це відразу відчувають.

Правомірним буде тут нагадати одне 3 правил для виховання, яких дотримувався Л.М. Толстой: «Краще, щоб діти знали про слабкі сторони своїх батьків, ніж те, щоб вони відчували, що $\epsilon$ в їхніх батьків приховане від них життя та $\epsilon$ показне. Всі труднощі виховання витікають 3 того, що батьки, не тільки не виправляючись від своїх недоліків, але навіть не визнаючи їх недоліками, виправдовуючи їх в собі, хочуть не бачити цих недоліків у дітях. В цьому вся важкість і вся боротьба з дітьми» [23]. На нашу думку, ці слова великого письменника можна віднести і до роботи педагога.

Ще раз відмітимо, що етика відносин на рівні «викладач - студент» якісно відрізняється від взаємовідносин в ході шкільної освіти. У вищій школі викладача і студента «поєднує» професія. В системі педагогічного спілкування вищої школи процес навчання поступово замінюється процесом співробітництва, в якому педагог і студент ідуть до однієї мети. В цьому процесі обидві сторони мають бути відвертими в своїх емоціях. Саме на цьому акцентував свою увагу великий український педагог В. Сухомлинський [24].

На жаль, у взаємовідносинах педагога i студента достатньо часто виникають конфліктні ситуації. Дуже часто самі педагоги стають джерелом конфлікту, якщо для них є характерними: авторитарний стиль спілкування; завищені вимоги; жорстка, непримиренна позиція; нечесність; несправедливі судження на адресу окремих учнів; лукавство; невиправдане втручання у взаємовідносини учнів; ігнорування індивідуальних та вікових особливостей учнів; несправедлива, занижена або завищена оцінка діяльності учня та ін. [6].

Безумовно, педагог повинен запобігати появі конфліктних ситуацій. Але якщо вони виникли, навіть в найкритичнішій ситуації, педагог має піклуватися про культуру своєї мови та спілкування. В його мові не має бути лайок, вульгаризмів, грубих та образливих фраз. В контексті акцентуємо увагу на необхідність детальнішого дослідження концепції естетичного виховання красотою, теоретиком i практиком якої став В. Сухомлинський.

Справжній педагог - це, насамперед, людина, яка вміє слухати та співчувати. Саме тому важливо надавати студентам можливість висказати свою точку зору, свою аргументацію, своє бачення 3 того чи іншого питання. Неможна заздалегідь критикувати дії студента. 
Педагогічна етика, на думку більшості вчених визначається багато в чому дотриманням педагогічного такту [17]. Саме безтактність $є$ першопричиною конфліктних ситуацій в педагогічній практиці.

Часто вийти 3 конфліктної ситуації допомагає гумор. Чи не тому так багато існує анекдотів про «доцентів і студентів».

Вміння 3 гідністю вийти 3 конфліктної ситуації особливо важливо при колективній роботі. Тому важливо навчити студента цій рисі педагогічної етики, щоб у своій подальшій виробничій діяльності він зміг уникнути небажаних ситуацій.

На закінчення хотілося б відмітити, що етичний саморозвиток педагога вищої школи має включати в себе культурний i патріотичний розвиток. В Законі України «Про вищу освіту» [21] відмічено, що основним завданням установи вищої освіти $\epsilon$ «формування особистості шляхом патріотичного, правового, екологічного виховання, затвердження у учасників освітнього процесу моральних цінностей, соціальної активності, громадської позиції та відповідальності, здорового образу життя, вміння вільно мислити та самоорганізовуватися в сучасних умовах».

Педагог вищої школи в своїй професійній діяльності повинен враховувати, що «головною хворобою XXI століття $\epsilon$ моральне саморуйнування людини, яке відбувається внаслідок нестримного прагнення людей до матеріального збагачення будь-якою ціною та невірно зрозумілої свободи як уседозволеності, що завдає непоправної шкоди й навколишньому світу, й самій людині» [6].

Педагог - це людина культури. Він сам - носій культури. В громадській свідомості педагог завжди був і залишається зразком культури. Ядро його особистості складають, так звані, загальнолюдські гуманістичні цінності морального, гносеологічного, естетичного порядку [25].

Тому такими важливими $\epsilon$ неофіційні, нерегламентовані контакти викладачів і студентів: бесіди «про науку, політику, мистецтво, професії, книги, музику». При цьому важливо, щоб викладачі брали активну участь в студентському дозвіллі. Огляди, конкурси, вечори, спортивні заходи мають стати майданчиками спілкування викладачів i студентів.

Це тим більше важливо, що останнім часом в психології введене поняття «гедон» - це умовна одиниця радості та задоволення незалежно від джерела їхнього походження. Здоров'я та благополуччя людини багато в чому залежать від здатності насолоджуватися кожним прожитим днем i не помічати дрібні неприємності. Все це дуже важливо для педагогічної професії, оскільки від позитивного настрою педагога залежить загальний педагогічний настрій всієї його діяльності [6].

Етика конкретного педагога формує патріотичну самосвідомість значної частини суспільства - української молоді. Тому важливо розвивати етичні та виховні традиції вишів.

Висновки. Проведені теоретичні дослідження та аналіз навчальної практики в установах вищої школи свідчать про необхідність розробки Кодексу професійної етики вітчизняного викладача вищої школи. В основу зазначеного документу мають бути покладені загальні принципи етичного спілкування, найкращі результати досвіду роботи вітчизняних та зарубіжних навчальних закладів.

\section{ПЕРЕЛІК ВИКОРИСТАНИХ ДЖЕРЕЛ}

1. Мудрость тысячелетий / сост. Е.А. Павликова. Москва: Абрис, 2017. 256 с.

2. Колокольникова 3.У., Данцева A.В. Проблема педагогической этики в трудах отечественного педагога середины XIX - начала XX в. Международный журнал прикладных и фундаментальных исследований. 2015. №2. С. 148-153.

3. Персонал. Словарь понятий и определений / Журавлев П.В., Карташов 
С.А, Маусов Н.К., Одегов Ю.Г. Москва: Экзамен, 1999. 512 с.

4. Гришин Э.А. Профессиональноэтическая подготовка учителя в системе высшего педагогического образования. Владимир: Свет, 1973. 309 с.

5. Асадуллин Р.М., Фролов О.В. Кризис педагогической культуры и некоторые задачи современной педагогической мысли. Образование $u$ наука. 2017. №2, т. 19. С. 9 - 25.

6. Андреев В.И. Педагогическая этика: инновационный курс для нравственного саморазвития. Казань: Центр инновационных технологий, 2012. 272 с.

7. Цыбулевская О.И., Касаева Т.В. Профессиональные этические стандарты в правовом поле России. Право и современное государство. 2013. №3. С. $29-34$.

8. Якушева С. Д. Педагогическая этика как элемент мастерства преподавателя вуза. Вестник Новгородского государственного университета. 2011. № 64. С. 69-72.

9. Дикань В.Л., Компанієць В.В., Полякова О.М. Етичні основи бізнесу: навчальний посібник. Харків: УкрДАЗТ, 2012.316 c.

10. Kompaniets V., Polevaya V., Poliakova E., Shramenko E. Readiness of workers for a new economy in condition of systemic changes (man - technologies economy). SHS Web of Conferences: Fifteenth Scientific and Practical International Conference "International Transport Infrastructure, Industrial Centers and Corporate Logistics". 2019. Vol. 67. DOI: https://doi.org/10.1051/shsconf/20196706028.

11. Шмелев А.Г. Кодекс профессиональной этики преподавателяэкзаменатора. Веб-сайт. URL: http://www.psy.msu.ru/educat/dnevn/test/codex .html (дата обращения: 15.08.2019).

12.

Одинцова

O.B. Профессиональная этика: учебник для студ. учреждений высшего образования. Изд. 3-е, стер. Москва: Издательский центр «Академия», 2014. 144 с.

13. Афонин А.С. Трудовое поведение. Киев: Украина, 1991. 159 с.

14. Сухомлинский В.А. Сердце отдаю детям. Рождение гражданина. Письма к сыну. Киев: Радянська школа, $1985.559 \mathrm{c}$.

15. Якушева С.Д. Этические аспекты профессиональной деятельности преподавателя вуза. $B$ мире научных открытий. 2010. № 5-3 (11). C.114-120. URL: http://naukarus.com/eticheskie-aspektyprofessionalnoy-deyatelnosti-prepodavatelyavuza. (дата обращения: 15.08.2019).

16. Сухорукова Т.Г. Роль ділового етикету у підвищенні економічної безпеки підприємства. Вісник економіки транспорту і промисловості. 2017. № 57. С. $38-45$.

17. Мишина Т.Н., Мишин В.М. Формирование педагогического такта преподавателя высшей школы. Международный журнал экспериментального образования. 2015. № 12 , ч. 2. C. 252-254. URL: https://www.expeducation.ru/ru/article/view?id =9075 (дата обращения: 15.08.2019).

18. Астафьева Е.Н. Об образовании народа и педагогике свободы (Рецензия Н.Г. Чернышевского на журнал «Ясная поляна»). Историко-педагогический журнал. 2013. №3. C.118-125.

19. Хлістунова Н. В. Формування системи комунікацій у навчальновиховному процесі ВНЗ. Ефективна економіка. 2016. № $1 . \quad$ URL: http://www.economy.nayka.com.ua/?op=1\&z= 4736 (дата звернення: 05.09.2019).

20. Компанієць В.В., Польова В.В. Управління трудовою поведінкою працівників підприємств залізничного транспорту (соціокультурні домінанти): монографія. Харків: Лідер, 2016. 298 с.

21. Про вищу освіту: Закон України від 1 липня 2014p. № 1556-VII: [офіц. текст: станом на 01 січня 2019 p.]. URL: https://zakon2.rada.gov.ua/laws/show/1556-18. (дата звернення: 08.01.2019).

22. Левитан К.М. Основы педагогической деонтологии: учеб. пособ. Москва: Наука, 1994. 102 с. 
23. Толстой Л.Н. Педагогические сочинения / сост. Н.В. Вейкшан (Кудрявая). Москва: Педагогика, 1089. 544 с.

24. Сухомлинский О.В. Хрестоматия по этике. Москва: Педагогика, 1990. 303 с.

25. Компанієць В. В. Управління розвитком соціально-економічних систем у духовно-моральному та соціокультурному вимірі. Частина 2. Якість управління соціально-економічними системами: духовно-моральні та культурні пріоритети (на прикладі залізничного транспорту): монографія. Харків: УкрДАЗТ, 2012. 296 с.

\section{REFERENCES}

1. (2017) Mudrost nuisjachiletiyi [The Wisdom of Millennia]. Moskva. Abris. (in Russian).

2. Kolokol'nikova Z.U., Dantseva A.V. (2015) Problema pedagogicheskoy etiki V trudakh otechestvennogo pedagoga serediny XIX - nachala XX $v$ [The Problem of Pedagogical Ethics in the Writings of a Domestic Teacher in the Mid-19th - Early 20th Centuries] International Journal of Applied and Basic Research. No 2, pp. 148-153.

3. Zhuravlev P.V., Kartashov S.A, Mausov N.K., Odegov Ju.G. (1999) Personal. Slovar' ponyatiy $i$ opredeleniy [Staff. A Dictionary of Concepts and Definitions]. Moskva: Ekzamen. (in Russian).

4. Grishin E.A. (1973) Professional'noeticheskaya podgotovka uchitelya $v$ sisteme vysshego pedagogicheskogo obrazovaniya [Professional and Ethical Training of Teachers in Higher Education]. Vladimir: Svet. (in Russian).

5. Asadulin R. M., Frolov O. V. (2017) Krizis pedagogicheskoi kulturiy I nekotoriue zadacyi sovremenoi pedagogicheskoi miusli [The Crisis of Pedagogical Culture and Some Tasks of Modern Pedagogical Thought]. Education and science, t. 19, no.2, pp. 9 - 25.

6. Andreev V.I. (2012) Pedagogicheskaya etika: innovatsionnyy kurs dlya nravstvennogo samorazvitiya [Pedagogical Ethics: an Innovative Course for Moral Self-Development]. Kazan': Tsentr innovatsionnykh tekhnologiy. (in Russian).

7. Zciubulevskaya O.I., Kasaeva T.V. (2013) Profesionalniue eticheskie standartiu v pravovom pole Rosii [Professional Ethical Standards in the Legal Field of Russia]. Law and the modern state, no. 3, pp. 29 - 34.

8. Yakusheva S. D. (2011) Pedagogicheskaya etika kak element masterstva prepodavatelya vuza [Pedagogical Ethics as an Element of a University Teacher Skill] The bulletin of Novgorod State University. No 64, pp. 69-72.

9. Dykan V.L., Kompaniiets V.V., Poliakova O.M. (2012) Etychni osnovy biznesu [Ethical Foundations of Business]. Kharkiv: UkrDAZT. (in Ukrainian).

10. Kompaniets V., Polevaya V., Poliakova E., Shramenko E. Readiness of workers for a new economy in condition of systemic changes (man - technologies economy). SHS Web of Conferences Volume 67 (2019). Fifteenth Scientific and Practical International Conference "International Transport Infrastructure, Industrial Centers and Corporate Logistics". DOI:

https://doi.org/10.1051/shsconf/201967 06028.

11. Shmelev A.G. Kodeks professional'noy etiki prepodavatelyaekzamenatora [The Professional Ethics Code of the Teacher-Examiner]. Available at: http://www.psy.msu.ru/educat/dnevn/test/codex .html.

12. Odintsova O.V.

Professional'naya etika. [Professional Ethics]. Moskva: Akademiya. (in Russian).

13. Afonin A.S. (1991) Trudovoe povedenie [Labor Behavior]. Kiev: Ukraina. (in Russian).

14. Sukhomlinskiy V.A. (1985) Serdtse otdayu detyam. Rozhdenie grazhdanina. Pis'ma $k$ synu [I Give the Heart to the Children. Birth of a Citizen. Letters to the Son]. Kiev: Radyans'ka shkola. (in Russian).

15. Yakusheva S.D. (2010) Eticheskie aspekty professional'noy deyatel'nosti prepodavatelya vuza [Ethical Aspects of a University Teacher Professional Activity] In the world of scientific discoveries. No 5-3 (11), 
pp.

114-120.

Available

at:

http://naukarus.com/eticheskie-aspekty-

professionalnoy-deyatelnosti-prepodavatelya-

vuza.

16. Sukhorukova T.H. (2017) Rol dilovoho etyketu u pidvyshchenni ekonomichnoi bezpeky pidpryiemstva [The Role of Business Etiquette in Improving the Economic Security of the Enterprise] The bulletin of Transport and Industry Economics. No 57, pp. 38-45.

17. Mishina T.N., Mishin V.M. (2015) Formirovanie pedagogicheskogo takta prepodavatelya vysshey shkoly [The Formation of the Pedagogical Tact of a High School Teacher] International Journal of Experimental Education. No 12, pp. 252-254. Available at: https://www.expeducation.ru/ru/article/view?id $=9075$.

18. Astaf'eva E.N. (2013) Ob obrazovanii naroda i pedagogike svobody (Retsenziya N.G. Chernyshevskogo na zhurnal «Yasnaya polyana») [On the Education of the People and the Pedagogy of Freedom (Review by N. G. Chernyshevsky on the magazine "Yasnaya Polyana")]. Historical and pedagogical Bulletin, no. 3, pp. 118-125.

19. Khlistunova N. V. (2016) Formuvannia systemy komunikatsii u navchalno-vykhovnomu protsesi VNZ [Formation of Communication System in Educational Process of Higher Education Institution]. Effective economy. no. 1. Available at:

http://www.economy.nayka.com.ua/?op=1\&z= 4736.
20. Kompaniets V.V. Poljova V.V. (2016) Ypravlinnja trudovoju povedunkoju pratzivnikiv pidpriemstv zaliznuchnogo transportu (sozioculturni dominants) [Railway Transport Employees' Behavior Management (Socio-Sultural Dominant)]. Kharkiv: Lider. (in Ukrainian).

21. Pro vyshchu osvitu: zakon Ukrainy vid 1 lypnia 2014r. № 1556-VII (ofits. tekst: stanom na 01 sichnia 2019 r.) [About Higher Education] Available at: https://zakon2.rada.gov.ua/laws/show/1556-18.

22. Levitan K.M. (1994) Osnovy pedagogicheskoy deontologii [Fundamentals of Pedagogical Deontology]. Moskva: Nauka. (in Russian).

23. Tolstoy L.N. (1089) Pedagogicheskie sochineniya. [Pedagogical Essays]. Moskva: Pedagogika. (in Russian).

24. Sukhomlinskiy O.V. (1990) Khrestomatiya po etike. [Anthology by Ethics] Moskva: Pedagogika. (in Russian).

25. Kompaniiets V. V. (2012) Upravlinnia rozvytkom sotsialnoekonomichnykh system u dukhovno-moralnomu ta sotsiokulturnomu vymiri. Chastyna 2. Yakist upravlinnia sotsialno-ekonomichnymy systemamy: dukhovno-moralni ta kulturni priorytety (na prykladi zaliznychnoho transportu) [Management of Socio-Economic Systems Development in the Spiritual-Moral and Socio-Cultural Dimension. Part 2. Quality Management of Socio-Economic Systems: Spiritual, Moral and Cultural Priorities (on the Example of Railway Transport)]. Kharkiv: UkrDAZT. (in Ukrainian) 